\title{
Modeling The Green Marketing and Green Supply Chain Management in The Context of Supply Chain Risk Management Toward Sustainability
}

\author{
Yuary Farradia ${ }^{1}$, Abdul Talib Bon ${ }^{2}$ \\ \{juaryfarradia@yahoo.com ${ }^{1}$, talib@uthm.edu.my ${ }^{2}$ \} \\ Faculty of Economics - Universitas Pakuan - Bogor, Indonesia ${ }^{1,}$ Faculty of Technology and \\ Management - Universiti Tun Hussein Onn - Malaysia ${ }^{1,2}$
}

\begin{abstract}
Consequences of both social, economic, and environmental within their operations and daily actions are required by industry sustainability. Sustainability issues relate to businesses operation carrying out firm commitment by responding to basic overall environmental issues. With regard to supply chain systems, knowledge of understanding risks and how to manage them in order to be of benefit to managers to reduce their consequences is very important. The environment, demand, supply, and process control are factors that usually attract attention. The model findings illustrate the model relationship between GMM and GSCM towards sustainability in terms of supply chain risk management. Greening management of supply chain will become best effort to prevent any risk of the supply chain, namely environment and economic (profitability) protection.Furthermore, GMM is also needed to maintain economic sustainability.
\end{abstract}

.Keywords Green, Supply Chain Management, Marketing, Sustainability, modeling

\section{Introduction}

Industry sustainability requires some consequences of environmental, economic, and social inside their processing and routine work. That is, the reduction of environmental pollution, while in the downstream this also occurs in the welfare of the community, thus affecting economic performance known as the triple bottom line. In addition, the Triple bottom line having as subordinated issues as stated by European Commission (2013) are:

- Social: covers not only local community but also employees, solicitors and clients

- Economy: financial performance with its effect on any development of economic indicators and comply with principle business ethics; and

- Environment: broad effect from campaign programs relate to utilization of environment, natural resources, rejection of all nature, control of territory;

Implementation of the triple bottom line in the manufacturer can be done through both execution and control of raw materials flow efficiency, planning process, supply chain management, related information flow, inventories process as well as finished products. Transporters, warehouses, retailers, and customer themselves are the thing covered by supply chain besides manufacturer and suppliers,. Involving linking marketing and supply chain alignment is also be needed. (Leppelt et al. 2013) 
Research on green supply chain management (GSCM) has seriously concern on the environmental leverages and jeopardies to human health from industrial activities (Barari, 2012). Green supply chains concern on various process and activities related to its supplier within business perspectives. Adding green concept in supply chain refer to the supply chain perspective by including the natural environment. Zhu and Sarkis (2004) states that GSCM integrates the supply chains starting from supplier, to manufacturer, to customer and reverse logistics.

Business activities in green supply chain, consists of risk factors and or drivers as well as various risks (Ruimin et al., 2012). (Hayati et al., 2014) stated that it is always important to concern on managing the supply chain risk because there are balance of both opportunity and uncertain risk within the industry

This paper emphasizes the model of green marketing (GM) and GSCM as the implications of supply chain risk management (SCRM). Finally, appropriate model of the GM and the GSCM within the context of the SCRM toward sustainability is reviewed.

Sustainability

Sustainability relates to how businesses concern on corporate responsibility to respond various matters on global environmental. Indeed, the corporate sector need to mediate the conflicts between economic imperatives and environmental goals in order to minimize harm of natural environment (Roxas \& Chadee, 2012). There are some taxonomies used for sustainability indicator such as triple bottom line (TBL) concepts, 3P's covers profit, planet and people (Burritt, 2012) and 3E's namely economics, environment and equity (Thnawala, 2001).

To achieve firm sustainability in the heavily business competitive atmosphere, most companies do various effort in order to reduce operational expenses and to serve the customers better. Other effort is aimed to reduce the risk of the disorders in inventories and predicting the future as well as designing and managing the supply chain effectively (Burgess et al., 2006). Thus companies which figure out the way to improve their SCM able to have better performance within the competitive market (Jain et al., 2010).

\section{Supply Chain Risk (SCR)}

In regard to the system of supply chain, it is important to get knowledge on risk understanding and its management to get greatly beneficial in minimize various consequences ( (Juttner 2005). March and Shapira (1987) explore an understanding of risk in the field of SCM eg. risk as "a divergence in the possibility of supply chain outcomes distribution, their likelihood, and their subjective values".

Identifying and understanding the sources of risk in the supply chain reviewed by Zsidisin et al. (1999), Johnson (2001), and Mason-Jones and Towill (1998). Further more, demand, supply, environment, and process control are important factors in risk sources. Srivastava, (2007) stated that SM need to integrate the dimension of environmental for designing the products, purchasing activities, material options, manufacturing process up to product delivery to the end of consumer.

\section{Green Supply Chain Management (GSCM)}

The GSCM is one of famous programs in environmental friendly business activities (Chen et al., 2012). This program results in lower cost to significant advantages and profit as well as responsible towards the environment issues for companies (Nikbakhsh, 2009). In addition, sustainable business and improvement of organizational performance could be achived by the GSCM practices and its elements (Rahim et al., 2016). GSM propose to 
considere the environmental challenges of all the product life cycle stages. These challenges constitute performance green goals.

In petrochemical industry, GSCM guides internal environmental management, environmental regulations, green purchasing, cleaner production, recovery, eco-design and pollution, reverse logistic, green supplier, customers collaboration, green innovation and return on investment (return investment) (Khaksar et al., 2015).

From the SCM perspective, external and internal factors in adopting environmental practices, defined as management practices to reduce various materials usages, innovate an eco-design products, up to sustaining the impact of environmental systems. Green et al., (2012) recommend firm to take internal factors of GSCM before adopting the external GSCM. This recommendation is supported by the study of Zhu et al., (2012) as firm performance was improved by adopting the internal GSCM and external GSCM, respectively. Environmental practices is involved in the supply chain and their business environments (Kim \& Chai, 2017). Chavez et al. (2014) study found a cost reduction benefit for manufacturers through customer-centric GSCM practices, as well as another benefit on quality improvement, delivery, and flexibility.

The external GSCM relates to the external factor of a firm such as with supplier and customer. The external GSCM variables used in terms of supplier is to green purchasing (GP) whislt reverse logistics (RL) is from the customer perspective.

Green purchasing (GP) refers to the procurement of products and services that reduced effect on human health and the environment and promoting recycling, reuse, resource reduction, and substitution of materials as well as reducing any sources of wastage (Carter \& Elrram, 1998; Min \& Galle, 2001; Zsidisin \& Siferd, 2001).

GP has focus priority to overcome various problem of sustainability in the purchasing so that not only focus on conventional purchasing criteria of cost, quality, and delivery (Jimenez \& Lorente, 2001; Kannan et al., 2008; Lambert \& Cooper, 2000). GP concern on any purchase of products and services which able to minimize harm factors on human health and the atmosphere when compared with competing products or services that serve the same purpose. (Vishal \& Avinash, 2016).

Reverse logistics adoption level has increased due to cost savings and revenues from returned products reason subject to the growing environmental concern (Roghanian \& Pazhoheshfa, 2014), means that the practice of reverse logistics particularly on product return would generate various savings cost from transportation, inventory and waste disposal. Reverse logistics is commonly known based on the 4Rs i.e. refund, restock, refurbish and recycle (Murray, 2012).

Internal GSCM practices, such environmental management systems able to repair operational performance measures such as quality, cost, utilization of various capacity, ontime delivery, and market positioning, create the shortest production lead time, better products and equipment selection decisions, degrade waste in production and rectify chances for selling products in the global markets (Lai \& Wong, 2012; Zhu et al. 2013). Yu et al. (2013) study also confirmed that internal GSCM influences operational performance in terms of delivery, flexibility, quality, and cost.

The internal GSCM practices are eco-design, internal environmental management, and investment recovery (Jabbour \& Sousa, 2015). Green et al., (2021), stated that corporations tend to take up internal GSCM first before external GSCM. Zhu et al., (2012) stated that external GSCM can remedy firms' performance after the adoption of internal GSCM 


\section{Green Marketing}

Green marketing is one important draft at which marketers are using these days as a solution way for sustainable development. Peattie \& Crane (2005) elaborated that green marketing tools such as eco-brand, eco-label, and environmental advertisement, will make insight easier and increase awareness of green products attributes and characteristics. Green marketing also plays an important role in performing sustainable development in the Business to Business (B2B) context (Arunachalam \& Burgh, 2013).

Green marketing covers policies, marketing activities, and procedures that allow the natural environment benefits in which these activities proposed to generate income in which resulting outcomes that fulfill the product or product line objectives of both the organization and individuals toward sustainability. Firm sustainability based on the strategic and financial goals can be attained via the concept of green marketing mix, particularly in terms of reducing the harmful effects on the natural environment.

Green marketing mix (GMM), as a marketing tools and elements are used to attain enterprise goals without harming the natural environment (Al-Salaymeh, 2013). Green products which involve the environmental protection is become a purchase motivation for family and friends, therefore it contributes long run development of sustainability in the country (Gopalakrishnan \& Muruganandam, 2013)

\section{Method}

The conceptual framework draws the relationship among the six constructs namely Internal GSCM, External GSCM, GMM and Sustainability. This study aims to explain the impact of Internal GSCM, and External GSCM with GMM on firm sustainability. In particular this study will elaborate that Internal GSCM and External GSCM are part of supply chain risk management effort.

This study reviewed of the previous research and data gathered from the current literatures. This study is also focus on the effectiveness of supply chain risk management efforts and analyzes the structural relationship between the constructs toward firm sustainability.

\section{Supply Chain Risk Management}

Various risks in supply chain can be categorized into industry, environment, and organizational risks (Rao and Goldsby, 2009). Some effort are needed To manage these various of supply chain risks to improve the supply chain performance through both reasonable trade-offs and balance situations between the among economic, environment and social sustainability. As the result, evaluation and selection of suppliers should be based on environmental and social standards elements subject to the implementation of supply chain risk management. One of the action on this associated risk management is to respond any social by developing various strategy on supplier development, coordination and obedience (Yawar and Seuring 2017).

\section{Internal Green Supply Chain Management}

Greening the manufacturing process can be done through implementation the internal GSCM where organization may enforce staff awareness on various internal environment management program and also designing programs of eco product as well as production process. A good policy in managing the environmental can ensure a guarantee of better financial performance (Yuhui, 2014). Hence, managing risk trough green manufacturing concept is the most important part of the financial performance of enterprises (Dongying et al., 


\section{External Green Supply Chain Management}

Greening the manufacturing process is also be done from the support of external GSCM factors such purchasing activity. Purchasing risk management become the most important part for environmental performance. Thus it is very important to implement the green purchasing as part of supply chain risk management. In relate to the customer side of the supply chain, a reverse logistics is the next important point for the supply chain risk management.

\section{Green Marketing Mix}

Green marketing mix dimension are green product, green price, green promotion and green distribution. Dongying et al. (2017) study found that there was an effect of green marketing risk to both financial and environment performance. Farradia (2019) find that GMM has significant relationship with both internal and external GSCM. Further her study also find that GMM plays as mediator between internal and external GSCM with sustainability.

\section{Model Development}

A model of the GMM and GSCM in the context of Supply Chain Risk Management toward sustainability can be developed as below:

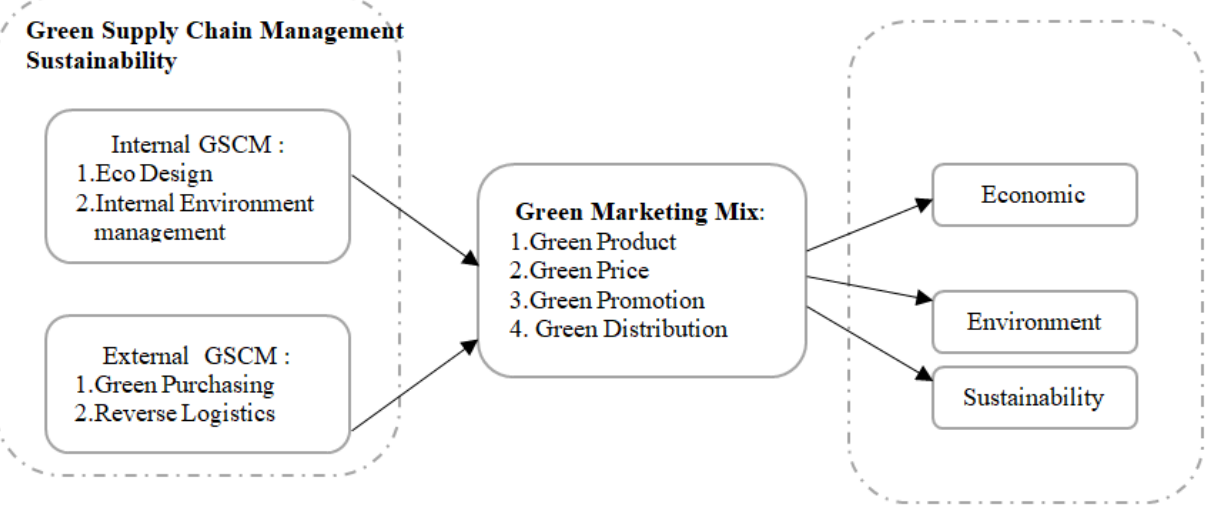

Figure 1. Conceptual Model

\section{Result and Discussions}

The model development as illustrated at figure 1, describes the role of both GSCM and GMM as a part of the supply chain risk management. Greening the supply chain as well as the marketing can fulfilled the environment risk management. Green products to meet customers' needs and wants could be driven by green marketing (Polonsky, 1994). Leonidou et al. (2013) study concluded the benefit of green marketing program on firms' performance and Fraj et al. (2011) reported that green marketing strategy support the firms to manage their 
resources efficiently and improve corporate image and reputation and leads firms to improve profitability.

The above literatures and various studies indicates that the dimension of green marketing mix such as product, price, place or distribution and promotion are applied as a green marketing strategy to generate sales which can strengthen the competitive advantage toward firms' profitability. Green marketing mix encourages a greener pattern of consumption among consumers. Green promotion as the communication media for green product and the services. Another advantage through this green campaign also will enhance the corporate image subject to the social responsibility.

Internal GSCM concern on the innovation concept of environmental preservation in designing the products. Thus, the success internal environment management enforcement to the organization will lead to green manufacture vision. Whilst the eco design implementation would generate green product and green process which influence the firms' performance. In particular for the environment risk management.

External GSCM more focus to both customer and supplier relationship. Thus the best risk management from external supply chain will impact to the firms' indicators for economic performance such as sales growth, market share up to the financial returns as well as the overall aspects of operational performance in order to increase the efficiency and to improve the quality of products.

Finally, various variables that link to the supply chain management within this study are analyzed based on the development framework for supply chain risk management toward firm sustainability.

\section{Conclusion}

The model illustrates the relationship between GMM and GSCM toward sustainability within the scope of supply chain risk management. Greening the supply chain management will become best effort to prevent any risk of the supply chain, namely environment and economic (profitability) protection. Furthermore, GMM also play an important role to maintain the economic sustainability as GMM can do green promotion continuously as well as creating the green product and green distribution innovation which will increase the margin set by the green pricing.

\section{Acknowledgements}

This research was supported by Universiti Tun Hussein Onn Malaysia and Universitas Pakuan, Bogor - Indonesia. Some direct observation and preliminary interview are contributed from some manufacturers in Banten Province - Indonesia

\section{References}

[1] Al-Salaymeh, M. (2013). The Application of the Concept of Green Marketing in the Productive Companies from the Perspective of Workers. Interdisciplinary journal of contemporary research in business. 4(12):634- 641. 
[2] Arunachalam, N., and de Burgh, H. (2013). Does Sustainability Matter in the B2B Environment: A Study in Marketing Attitudes and the Constraints of "Going Green" in the B2B context. ANZMAC 2013.

[3] Barari, S. A. (2012). A decision framework for the analysis of green supply chain contracts: An evolutionary game approach. Expert systems with applications, 39(3): 2965-2976.

[4] Carter, C. R., and Ellram, L. M. (1998). Reverse logistics: a review of the literature and framework for future investigation. Journal of business logistics, 19(1), 85.

[5] Chavez, R., Yu, W., Feng, M., Wiengarten, F,. (2014). The Effect of Customer Centric Green Supply Chain Management on Operational Performance and Customer Satisfaction. Business Strategy and The Environment, 25 (3).

[6] Chen, C., Shih, H., Shyur, H., \& Wu, K. (2012). A business Strategy Selection of Green Supply Chain Management via An Analytic Network Process. Computers and Mathematics with Applications, 64, 2544-2557

[7] Dongying, Z., Yuting, D., and Junyi, S. (2017). Influence of green supply chain risk management on performance of Chinese manufacturing enterprises. IOP Conf. Ser.: Earth Environ. Sci. 100 012184

[8] European Commission, http://ec.europa.eu/ .(2013)

[9] Farradia, Y. (2019). Sustainability firm performance of green supply chain management practice at petrochemical industry in Indonesia. PhD thesis. Universiti Tun Hussein Onn. Malaysia

[10] Fraj, E., Martínez, E., and Matute, J. (2011). Green marketing strategy and the firm 's performance : the moderating role of environmental culture. Journal of Strategic Marketing, 19(4), 339-355. doi:10.1080/0965254X.2011.581382

[11] Gopalakrishnan MS, and Muruganandam, D. A (2013). Micro analysis on Dissect of Consumer's to Procure Green Products. Life Science Journal. 2013; 10(2)

[12] Green, K., Zelbst, P., Meacham, J. and Bhadauria, V. (2012). Green Supply Chain Management Practices: Impact on Performance. Supply Chain Management International Journal, Vol. 17 Iss. 3, pp. $290-305$.

[13] Hayati, M., Atai, M., Kakayi, R.K and Sayady, A.R. (2014). Offer supply chain risk assessment model using multi-criteria decision making techniques, Industrial Management Studies, Volume 12, No. 34, Winter 2014, pp 19-40

[14] Johnson, M. E. (2001). Learning from toys: Lessons in managing supply chain risk from the toy industry. California Management Review, 43(3), 106-124.

[15] Juttner, U., 2005. Supply chain risk management: understanding the business requirements from the practitioners perspective. International Journal of Logistics Management 16(1): 120-141.

[16] Khaksar, E., Kahanaali, R.A., Tizroo, A., \& Rad, F.B (2015). An analysis of the effective actions on green supply chain management using ISM method (Studying the petrochemical industry). $J$. Mater. Environ. Sci. 6 (7). pp. 1987-1996.

[17] Kim, M and Chai, S. (2017). Environmental Practices for Accomplishing Sustainable Green Supply Chain Management. Ewha School of Business, Ewha Womans University, 52 Ewhayeodaegil, Seodaemungu, Seoul 03760, Korea

[18] Lai, K., and Wong,C,.W.Y. (2012). Green Logistics Management and Performance: Some Empirical Evidence from Chinese Manufacturing Exporters. Omega, Vol 40 (3), pp. 267-282

[19] Leppelt, T., K. Foerstl, and E. Hartmann. (2013). Corporate social responsibility in buyer-supplier relationships: is it beneficial for top-tier suppliers to market their capability to ensure a responsible supply chain? Business Research 6: 126-152.

[20] Leonidou, C. N., Katsikeas, C. S., and Morgan, N. A. (2013). "Greening" the marketing mix: do firms do it and does it pay off? Journal of the Academy of Marketing Science, 41, 151-170. doi:10.1007/s11747-012-0317-2

[21] Mason-Jones R and Towill, D.R. (1998), "Shrinking the Supply Chain Uncertainty Cycle", Control, pp. 17-22.

[22] March J., and Shapira Z. (1987), "Managerial perspectives on risk and risk taking", Management Science.

[23] Min, H. and Galle, W. (2001), "Green purchasing practices of US firms", International Journal of 
Operations and Production Management, Vol. 21 No. 9, pp. 1222-1238.

[24] Nikbakhsh, E. (2009). Green supply chain management. Book chapter in Contributions in Management Science, pp. 195-220, Springer.

[25] Rahim, S.A., Fernando, Y., Saad, R (2016). Sustainable Green Supply Chain Management and Impact on Organizations. Journal of Emerging Trends in Economics and Management Sciences (JETEMS), 7(3): pp. 147-155.

[26] Ruimin, M., L. Yao and R. Huang. 2012. The Green Supply Chain Management Risk Analysis. Advanced Materials Research 573-574: 734-739.

[27] Roghanian, E. \& Pazhoheshfar, P. (2014). An optimization model for reverse logistics network under stochastic environment by using genetic algorithm. Journal of Manufacturing Systems 33 (2014) 348-356

[28] Srivastava, S.K., (2007). Green supply-chain management: a state-of-the- art literature review. International Journal of Management Reviews. 9(1), 53-80.

[29] Vishal, M.S., \& Avinash, S,. (2016). Green Supply Chain Management - An Overview. International Journal of Advanced Engineering and Innovative Technology (IJAEIT). ISSN No 2348-7208. Special Issue on "Emerging Technology for Innovative India".

[30] Yuhui L,. Shanbo Y, and Yangyang, Z. (2014). Effects of Environmental Performance on Financial Performance and Cooperative Countermeasures [J]. China Business, (19): 120-121.

[31] Yu, W., Jacobs, M.A., Salisbury, W.D., Enns, H., (2013). The effects of supply chain integration on customer satisfaction and financial performance: An organizational learning perspective. International Journal of Production Economics 146 (1), 346-358

[32] Zhu, Q., and Sarkis, J., (2004). Relationships between operational practices and performance among early adopters of green supply chain management practices in Chinese manufacturing enterprises, Journal of Operations Management, vol. 22, 265-289.

[33] Zhu, Q., Sarkis, J,. Lai, K. (2012). Examining the Effects of Green Supply Chain Management Practices and Their Mediations on Performance Improvements. International Journal of Production Research, 50(50), pp. 1377 - 1394.

[34] Zsidisin, G.A., Panelli A., and Upton R. (1999), "Purchasing organization involvement in risk assessments, contingency plans and risk management: an exploratory study", Supply Chain Management; An International Journal, Vol. 5, No. 4, pp. 187-197.

[35] Zsidisin, G.A. and Siferd, S.P. (2001), "Environmental purchasing: a framework for theory development", European Journal of Purchasing and Supply Management, Vol. 7 No. 1, pp. 6173

[36] Journal of Sustainable Development Studies. ISSN 2201-4268 Volume 6, Number 1, 2014, 71-95 